\title{
Genetic Diversity Between and Within Astrocaryum acaule Mart. (Arecaceae) Populations
}

\author{
Aline Araújo Patrício Lima ${ }^{1}$ (1) 0000-0003-0478-1433 \\ Maria Teresa Gomes Lopes ${ }^{1}$ (1) 0000-0003-1988-7126 \\ Mágno Sávio Ferreira Valente ${ }^{2}$ (1) 0000-0003-4730-0062 \\ Santiago Linorio Ferreyra Ramos ${ }^{3}$ (D) 0000-0003-0364-316X \\ Edvan Alves Chagas ${ }^{4}$ (D) 0000-0001-8604-7819 \\ Júlio César Gonçalves de Souza ${ }^{1}$ [D 0000-0001-5285-9480
}

\begin{abstract}
This article sought to assess the genetic diversity within and between natural populations of Astrocaryum acaule by means of AFLP markers. Ninety individuals were sampled in three populations located in Manaus (state of Amazonas) across regions with different intensities of anthropogenic activity. Two clusters were differentiated by means of dendrograms and Bayesian cluster analysis, the first consisting of individuals from the Tarumã-Açu population in an intensely agricultural region, and the second, of populations from UFAM and Tupé conservation areas. The physical isolation of $A$. acaule populations has resulted in good conservation of its genetic identity, since anthropogenic activity is an important modifier of the genetic diversity of natural populations. Genetic diversity was higher within populations $(74.58 \%)$ than between them $(25.42 \%)$, which means that we have to collect representative samples from each of the genetically distinct groups for genetic conservation of the species. Therefore, in situ conservation is recommended.
\end{abstract}

Keywords: Amazonian palm, genetic resource, AFLP, population structure.

\section{INTRODUCTION AND OBJECTIVE}

The Amazon region is rich in animal and plant diversity. Among the plant groups, palm trees of the species from the Arecaceae family stand out. Palm trees have different purposes, with usage in/as food and in construction, and also generate by-products that are sources of income for the survival of Amazonian populations (Wallace, 2014). Although having great potential for development in the region, the native palms of the Amazon are most present in the wild or semi-wild (Gomes et al., 2011), such as the Astrocaryum acaule Mart. (tucumanzinho) palm tree, which is still a neglected species in studies that would enable its better use.

Astrocaryum acaule has edible fruits with reduced size compared to Astrocaryum aculeatum (tucumã-do-Amazonas); moreover, its seeds are used for manufacturing biojewelery, being one of the species most frequently used for ring production in the Amazon region. The leaves are used for fiber extraction and these have suitable physical, chemical and organoleptic properties for producing natural tissues (Pacheco et al., 2011). The species has very interesting characteristics, such as its subterranean stem, which facilitates collection of fruits; its leaves, which sprout directly from the soil; and the peduncle of the spadix, which grows between the leaves with the fruits (Wallace, 2014). As A. acaule is very small, it can be considered for interspecific improvement with A. aculeatum to reduce the size of this important Amazon fruit tree. There are already indications of the existence of natural hybrids between these species; however, the studies that verify the viability of this crossing are still in the initial phase of experimentation.

Deforestation in the Amazon, either by extraction or for agricultural use, has been reducing the genetic variability of many

${ }^{1}$ Universidade Federal do Amazonas (UFAM), Manaus, AM, Brasil

${ }^{2}$ Instituto Federal do Amazonas (IFAM), Presidente Figueiredo, AM, Brasil

${ }^{3}$ Instituto de Ciências Exatas e Tecnologia (ICET/UFAM), Itacoatiara, AM, Brasil

${ }^{4}$ Empresa Brasileira de Pesquisa Agropecuária (EMBRAPA RORAIMA), Boa Vista, RR, Brasil 
tree species, including palm trees. This problem is believed to aggravate in populations present in urban areas, being necessary studies that evaluate the impacts on the genetic variability according to the intensity of the anthropic action in these populations. According to Viegas et al. (2011), when the forest becomes fragmented, the size of the populations decreases, and, consequently, their genetic diversity, making them isolated and vulnerable to environmental, demographic and genetic events.

The maintenance of genetic variability has become a key factor for species to maintain their ability to react to environmental stresses, especially in the face of global climate change (Cruz et al., 2011). Thus, it is necessary to know the quantification and distribution of genetic diversity among and within populations to outline usage and conservation strategies, aiming to overcome the challenges of environmental changes and the inadequate exploitation of native forests.

Studies of genetic variability in natural populations of palm trees in tropical regions show that they preserve great variability within the populations when compared with those existing in other environments such as the Euterpe edulis (juçara - palmito-juçara) (Cardoso et al., 2000), Butia capitata (jelly palm - butiá) (Buttow et al., 2010), Mauritia flexuosa (moriche palm - buriti) (Gomes et al., 2011), Astrocaryum aculeatum (tucumã) (Ramos et al., 2012) and Astrocaryum jauari (jauari) (Oliveira et al., 2014) palm trees. The distribution of natural genetic variability is influenced by factors such as breeding mode, crossing system, population size, geographic distribution and gene flow, as well as anthropic influence, which has been an agent that modifies the genetic diversity of many natural populations of many species (Viegas et al., 2011).

Based on the knowledge of genetic diversity among and within natural populations, it is possible to understand how selection is acting as a function of adaptability and to establish conservation strategies, since the greater the genetic variability in the population, the greater the chance of species perpetuation (Almeida et al., 2015; Rossi et al., 2014). Several techniques are used in studies of genetic diversity; among these, molecular markers of DNA enable identification of polymorphic loci in the genome and are not influenced by environmental effects. Amplified Fragment Length Polymorph (AFLP) markers are distinguished from other markers because they detect a large number of loci with wide genome coverage, and can be used for species with little or no previous molecular knowledge (Lopes et al., 2003).

This study sought to evaluate the genetic diversity among and within natural populations of the species by means of the AFLP molecular marker, since knowledge of the genetic variability of $A$. acaule populations is essential for the use, conservation and breeding of this species.

\section{MATERIALS AND METHODS}

The Astrocaryum acaule populations were studied in three distinct regions of the city of Manaus: the campus of the Universidade Federal do Amazonas (UFAM), the Julião Community located in the Tupé Sustainable Development Reserve (RDS) and Tarumã-Açu Community (study registered in SisGen under No. A96D1EA) (Figure 1).

This study consisted of 90 plants ( 30 of each population) randomly sampled, properly identified and with their geographical positions registered by GPS (Global Positioning System) (Table 1). The three collection sites had similar characteristics such as being sandy soils, floodable, and near water courses. In general, the $A$. acaule populations were composed of several individuals close to each other; however, a minimum distance of $100 \mathrm{~m}$ between individuals was observed at the time of collection.

Young and healthy leaves were harvested from each plant, packed in plastic bags containing silica gel, duly identified and stored at $-20^{\circ} \mathrm{C}$ for subsequent extraction of genomic DNA and analysis with AFLP markers in the Laboratory of Plant Genetic Improvement of the Faculdade de Ciências of UFAM. Genomic DNA was extracted using the 2\% CTAB method (cetyltrimethylammonium bromide) described by Murray \& Thompson (1980). For each sample, approximately $80 \mathrm{mg}$ of leaf tissue was macerated without the main vein. Analysis of the quality of the extracted DNA was performed by electrophoresis in $0.7 \%$ agarose gel, and the DNA was quantified by absorbance measurements under UV light (260 and $280 \mathrm{~nm}$ ) in a Vilber Lourmat spectrophotometer (Quantum model).

Analysis of AFLP markers was performed according to the procedures originally proposed by Vos et al. (1995), with modifications by Lopes et al. (2003). The combination of EcoRI/MseI restriction enzymes in $30 \mathrm{ng}$ of genomic DNA was used for the DNA digestion reactions. Specific EcoRI and MseI adapters were subsequently prepared, which had complementary ends to the extremities resulting from digestion by the restriction enzymes. In the selective amplification stage, three of the four combinations of tested primers $(\mathrm{E}+\mathrm{AAC} / \mathrm{M}+\mathrm{CAC}, \mathrm{E}+\mathrm{ACA} / \mathrm{M}+\mathrm{CGC}$ and $\mathrm{E}+\mathrm{AAC} /$ $\mathrm{M}+\mathrm{CGA}$ ) were selected due to the presence of a higher number of polymorphic loci and a better amplification quality of the bands. Therefore, they were used in all the samples. After the selective amplification reactions, each sample was applied to the Bio-Rad vertical electrophoresis cell (SEQUI Gen GT model) in 6\% polyacrylamide gel (acrylamide/bisacrylamide $(19: 1 \mathrm{v} / \mathrm{v})$ under constant potency of $80 \mathrm{~W}$ for four hours. The silver nitrate staining method was used for development of the gel, according to the protocol proposed by Creste et al. (2001). 


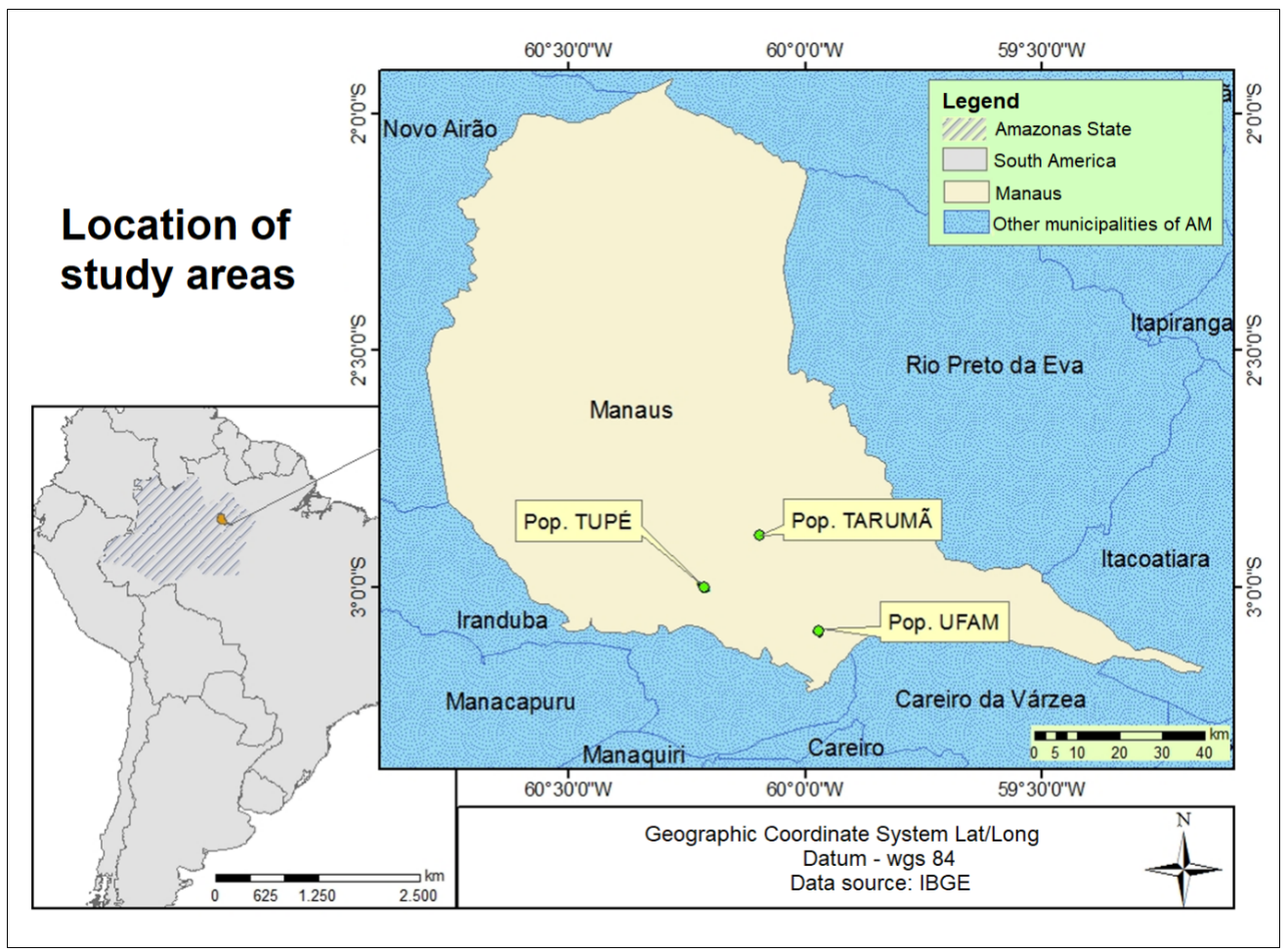

Figure 1. Location map of the Astrocaryum acaule study populations.

Table 1. Location of the 90 Astrocaryum acaule subsamples used in the genetic diversity study.

\begin{tabular}{|c|c|c|c|c|c|c|}
\hline \multicolumn{7}{|c|}{ Geographic Coordinates } \\
\hline \multirow{2}{*}{ ID } & \multicolumn{2}{|c|}{ UFAM (UF) } & \multicolumn{2}{|c|}{ RDS Tupé (TU) } & \multicolumn{2}{|c|}{ Tarumã-Açu (TA) } \\
\hline & Latitude & Longitude & Latitude & Longitude & Latitude & Longitude \\
\hline 1 & $-03^{\circ} 05^{\prime} 44.72^{\prime \prime}$ & $-59^{\circ} 58^{\prime} 31.72^{\prime \prime}$ & $-02^{\circ} 59^{\prime} 05.36^{\prime \prime}$ & $-60^{\circ} 11^{\prime} 52.19^{\prime \prime}$ & $-02^{\circ} 53^{\prime} 24.20^{\prime \prime}$ & $-60^{\circ} 05^{\prime} 53.40^{\prime \prime}$ \\
\hline 2 & $-03^{\circ} 05^{\prime} 42.19^{\prime \prime}$ & $-59^{\circ} 58^{\prime} 34.77^{\prime \prime}$ & $-02^{\circ} 59^{\prime} 05.49^{\prime \prime}$ & $-60^{\circ} 11^{\prime} 50.48^{\prime \prime}$ & $-02^{\circ} 53^{\prime} 25.40^{\prime \prime}$ & $-60^{\circ} 05^{\prime} 53.60^{\prime \prime}$ \\
\hline 3 & $-03^{\circ} 05^{\prime} 41.88^{\prime \prime}$ & $-59^{\circ} 58^{\prime} 33.80^{\prime \prime}$ & $-02^{\circ} 58^{\prime} 43.24^{\prime \prime}$ & $-60^{\circ} 11^{\prime} 30.05^{\prime \prime}$ & $-02^{\circ} 53^{\prime} 23.70^{\prime \prime}$ & $-60^{\circ} 05^{\prime} 54.40^{\prime \prime}$ \\
\hline 4 & $-03^{\circ} 05^{\prime} 42.20^{\prime \prime}$ & $-59^{\circ} 58^{\prime} 33.30^{\prime \prime}$ & $-02^{\circ} 58^{\prime} 43.64^{\prime \prime}$ & $-60^{\circ} 11^{\prime} 31.36^{\prime \prime}$ & $-02^{\circ} 53^{\prime} 23.60^{\prime \prime}$ & $-60^{\circ} 05^{\prime} 55.60^{\prime \prime}$ \\
\hline 5 & $-03^{\circ} 05^{\prime} 42.64^{\prime \prime}$ & $-59^{\circ} 58^{\prime} 32.87^{\prime \prime}$ & $-02^{\circ} 59^{\prime} 05.52^{\prime \prime}$ & $-60^{\circ} 11^{\prime} 52.17^{\prime \prime}$ & $-02^{\circ} 53^{\prime} 23.00^{\prime \prime}$ & $-60^{\circ} 05^{\prime} 56.70^{\prime \prime}$ \\
\hline 6 & $-03^{\circ} 05^{\prime} 42.02^{\prime \prime}$ & $-59^{\circ} 58^{\prime} 36.33^{\prime \prime}$ & $-02^{\circ} 59^{\prime} 53.90^{\prime \prime}$ & $-60^{\circ} 13^{\prime} 13.14^{\prime \prime}$ & $-02^{\circ} 53^{\prime} 23.70^{\prime \prime}$ & $-60^{\circ} 05^{\prime} 57.30^{\prime \prime}$ \\
\hline 7 & $-03^{\circ} 05^{\prime} 42.19^{\prime \prime}$ & $-59^{\circ} 58^{\prime} 35.22^{\prime \prime}$ & $-02^{\circ} 59^{\prime} 26.40^{\prime \prime}$ & $-60^{\circ} 13^{\prime} 28.24^{\prime \prime}$ & $-02^{\circ} 53^{\prime} 23.90^{\prime \prime}$ & $-60^{\circ} 05^{\prime} 53.80^{\prime \prime}$ \\
\hline 8 & $-03^{\circ} 05^{\prime} 41.74^{\prime \prime}$ & $-59^{\circ} 58^{\prime} 38.19^{\prime \prime}$ & $-02^{\circ} 59^{\prime} 26.08^{\prime \prime}$ & $-60^{\circ} 13^{\prime} 27.94^{\prime \prime}$ & $-02^{\circ} 53^{\prime} 23.50^{\prime \prime}$ & $-60^{\circ} 05^{\prime} 58.70^{\prime \prime}$ \\
\hline 9 & $-03^{\circ} 05^{\prime} 42.07^{\prime \prime}$ & $-59^{\circ} 58^{\prime} 35.88^{\prime \prime}$ & $-02^{\circ} 59^{\prime} 26.42^{\prime \prime}$ & $-60^{\circ} 13^{\prime} 28.40^{\prime \prime}$ & $-02^{\circ} 53^{\prime} 23.40^{\prime \prime}$ & $-60^{\circ} 05^{\prime} 59.20^{\prime \prime}$ \\
\hline 10 & $-03^{\circ} 05^{\prime} 43.27^{\prime \prime}$ & $-59^{\circ} 58^{\prime} 31.58^{\prime \prime}$ & $-03^{\circ} 00^{\prime} 25.13^{\prime \prime}$ & $-60^{\circ} 12^{\prime} 54.22^{\prime \prime}$ & $-02^{\circ} 53^{\prime} 23.10^{\prime \prime}$ & $-60^{\circ} 05^{\prime} 59.50^{\prime \prime}$ \\
\hline 11 & $-03^{\circ} 05^{\prime} 43.02^{\prime \prime}$ & $-59^{\circ} 58^{\prime} 31.91^{\prime \prime}$ & $-03^{\circ} 00^{\prime} 24.82^{\prime \prime}$ & $-60^{\circ} 12^{\prime} 53.82^{\prime \prime}$ & $-02^{\circ} 53^{\prime} 24.80^{\prime \prime}$ & $-60^{\circ} 05^{\prime} 58.60^{\prime \prime}$ \\
\hline 12 & $-03^{\circ} 05^{\prime} 44.03^{\prime \prime}$ & $-59^{\circ} 58^{\prime} 31.33^{\prime \prime}$ & $-03^{\circ} 00^{\prime} 18.22^{\prime \prime}$ & $-60^{\circ} 12^{\prime} 54.02^{\prime \prime}$ & $-02^{\circ} 53^{\prime} 25.20^{\prime \prime}$ & $-60^{\circ} 05^{\prime} 58.70^{\prime \prime}$ \\
\hline 13 & $-03^{\circ} 05^{\prime} 43.56^{\prime \prime}$ & $-59^{\circ} 58^{\prime} 31.56^{\prime \prime}$ & $-03^{\circ} 00^{\prime} 20.68^{\prime \prime}$ & $-60^{\circ} 12^{\prime} 19.64^{\prime \prime}$ & $-02^{\circ} 53^{\prime} 24.20^{\prime \prime}$ & $-60^{\circ} 05^{\prime} 58.50^{\prime \prime}$ \\
\hline 14 & $-03^{\circ} 05^{\prime} 42.67^{\prime \prime}$ & $-59^{\circ} 58^{\prime} 32.83^{\prime \prime}$ & $-03^{\circ} 00^{\prime} 26.21^{\prime \prime}$ & $-60^{\circ} 12^{\prime} 38.53^{\prime \prime}$ & $-02^{\circ} 53^{\prime} 26.30^{\prime \prime}$ & $-60^{\circ} 05^{\prime} 57.60^{\prime \prime}$ \\
\hline 15 & $-03^{\circ} 05^{\prime} 42.94^{\prime \prime}$ & $-59^{\circ} 58^{\prime} 32.16^{\prime \prime}$ & $-03^{\circ} 00^{\prime} 24.68^{\prime \prime}$ & $-60^{\circ} 12^{\prime} 46.43^{\prime \prime}$ & $-02^{\circ} 53^{\prime} 26.90^{\prime \prime}$ & $-60^{\circ} 05^{\prime} 56.90^{\prime \prime}$ \\
\hline 16 & $-03^{\circ} 05^{\prime} 42.18^{\prime \prime}$ & $-59^{\circ} 58^{\prime} 33.30^{\prime \prime}$ & $-03^{\circ} 00^{\prime} 23.87^{\prime \prime}$ & $-60^{\circ} 12^{\prime} 51.36^{\prime \prime}$ & $-02^{\circ} 53^{\prime} 27.70^{\prime \prime}$ & $-60^{\circ} 05^{\prime} 57.00^{\prime \prime}$ \\
\hline 17 & $-03^{\circ} 05^{\prime} 56.17^{\prime \prime}$ & $-59^{\circ} 58^{\prime} 12.98^{\prime \prime}$ & $-03^{\circ} 00^{\prime} 02.47^{\prime \prime}$ & $-60^{\circ} 13^{\prime} 06.60^{\prime \prime}$ & $-02^{\circ} 53^{\prime} 28.20^{\prime \prime}$ & $-60^{\circ} 05^{\prime} 56.50^{\prime \prime}$ \\
\hline 18 & $-03^{\circ} 05^{\prime} 56.79^{\prime \prime}$ & $-59^{\circ} 58^{\prime} 11.51^{\prime \prime}$ & $-02^{\circ} 59^{\prime} 53.90^{\prime \prime}$ & $-60^{\circ} 13^{\prime} 13.14^{\prime \prime}$ & $-02^{\circ} 53^{\prime} 28.90^{\prime \prime}$ & $-60^{\circ} 05^{\prime} 56.20^{\prime \prime}$ \\
\hline 19 & $-03^{\circ} 05^{\prime} 41.77^{\prime \prime}$ & $-59^{\circ} 58^{\prime} 37.10^{\prime \prime}$ & $-02^{\circ} 59^{\prime} 41.62^{\prime \prime}$ & $-60^{\circ} 13^{\prime} 22.68^{\prime \prime}$ & $-02^{\circ} 53^{\prime} 29.60^{\prime \prime}$ & $-60^{\circ} 05^{\prime} 54.80^{\prime \prime}$ \\
\hline 20 & $-03^{\circ} 05^{\prime} 56.16^{\prime \prime}$ & $-59^{\circ} 58^{\prime} 11.41^{\prime \prime}$ & $-02^{\circ} 59^{\prime} 30.59^{\prime \prime}$ & $-60^{\circ} 13^{\prime} 30.91^{\prime \prime}$ & $-02^{\circ} 53^{\prime} 30.10^{\prime \prime}$ & $-60^{\circ} 05^{\prime} 51.10^{\prime \prime}$ \\
\hline 21 & $-03^{\circ} 05^{\prime} 43.79^{\prime \prime}$ & $-59^{\circ} 58^{\prime} 32.18^{\prime \prime}$ & $-02^{\circ} 59^{\prime} 26.58^{\prime \prime}$ & $-60^{\circ} 13^{\prime} 28.11^{\prime \prime}$ & $-02^{\circ} 53^{\prime} 30.30^{\prime \prime}$ & $-60^{\circ} 05^{\prime} 53.90^{\prime \prime}$ \\
\hline 22 & $-03^{\circ} 05^{\prime} 55.92^{\prime \prime}$ & $-59^{\circ} 58^{\prime} 15.21^{\prime \prime}$ & $-02^{\circ} 59^{\prime} 26.40^{\prime \prime}$ & $-60^{\circ} 13^{\prime} 28.24^{\prime \prime}$ & $-02^{\circ} 53^{\prime} 30.80^{\prime \prime}$ & $-60^{\circ} 05^{\prime} 53.40^{\prime \prime}$ \\
\hline
\end{tabular}


Table 1. Continued...

\begin{tabular}{|c|c|c|c|c|c|c|}
\hline \multicolumn{7}{|c|}{ Geographic Coordinates } \\
\hline \multirow{2}{*}{ ID } & \multicolumn{2}{|c|}{ UFAM (UF) } & \multicolumn{2}{|c|}{ RDS Tupé (TU) } & \multicolumn{2}{|c|}{ Tarumã-Açu (TA) } \\
\hline & Latitude & Longitude & Latitude & Longitude & Latitude & Longitude \\
\hline 23 & $-03^{\circ} 05^{\prime} 55.75^{\prime \prime}$ & $-59^{\circ} 58^{\prime} 13.25^{\prime \prime}$ & $-03^{\circ} 00^{\prime} 25.10^{\prime \prime}$ & $-60^{\circ} 12^{\prime} 54.20^{\prime \prime}$ & $-02^{\circ} 53^{\prime} 29.00^{\prime \prime}$ & $-60^{\circ} 05^{\prime} 53.30^{\prime \prime}$ \\
\hline 24 & $-03^{\circ} 05^{\prime} 42.65^{\prime \prime}$ & $-59^{\circ} 58^{\prime} 34.18^{\prime \prime}$ & $-03^{\circ} 00^{\prime} 25.14^{\prime \prime}$ & $-60^{\circ} 12^{\prime} 54.20^{\prime \prime}$ & $-02^{\circ} 53^{\prime} 28.80^{\prime \prime}$ & $-60^{\circ} 05^{\prime} 52.70^{\prime \prime}$ \\
\hline 25 & $-03^{\circ} 05^{\prime} 43.45^{\prime \prime}$ & $-59^{\circ} 58^{\prime} 32.12^{\prime \prime}$ & $-03^{\circ} 00^{\prime} 25.05^{\prime \prime}$ & $-60^{\circ} 12^{\prime} 54.20^{\prime \prime}$ & $-02^{\circ} 53^{\prime} 30.20^{\prime \prime}$ & $-60^{\circ} 05^{\prime} 52.60^{\prime \prime}$ \\
\hline 26 & $-03^{\circ} 05^{\prime} 41.74^{\prime \prime}$ & $-59^{\circ} 58^{\prime} 38.19^{\prime \prime}$ & $-03^{\circ} 00^{\prime} 25.28^{\prime \prime}$ & $-60^{\circ} 12^{\prime} 54.49^{\prime \prime}$ & $-02^{\circ} 53^{\prime} 30.70^{\prime \prime}$ & $-60^{\circ} 05^{\prime} 52.70^{\prime \prime}$ \\
\hline 27 & $-03^{\circ} 05^{\prime} 41.97^{\prime \prime}$ & $-59^{\circ} 58^{\prime} 39.01^{\prime \prime}$ & $-03^{\circ} 00^{\prime} 25.24^{\prime \prime}$ & $-60^{\circ} 12^{\prime} 54.67^{\prime \prime}$ & $-02^{\circ} 53^{\prime} 30.60^{\prime \prime}$ & $-60^{\circ} 05^{\prime} 54.50^{\prime \prime}$ \\
\hline 28 & $-03^{\circ} 05^{\prime} 56.58^{\prime \prime}$ & $-59^{\circ} 58^{\prime} 11.88^{\prime \prime}$ & $-03^{\circ} 00^{\prime} 24.82^{\prime \prime}$ & $-60^{\circ} 12^{\prime} 53.82^{\prime \prime}$ & $-02^{\circ} 53^{\prime} 30.80^{\prime \prime}$ & $-60^{\circ} 05^{\prime} 54.10^{\prime \prime}$ \\
\hline 29 & $-03^{\circ} 05^{\prime} 55.80^{\prime \prime}$ & $-59^{\circ} 58^{\prime} 14.12^{\prime \prime}$ & $-03^{\circ} 00^{\prime} 18.17^{\prime \prime}$ & $-60^{\circ} 12^{\prime} 53.56^{\prime \prime}$ & $-02^{\circ} 53^{\prime} 32.00^{\prime \prime}$ & $-60^{\circ} 05^{\prime} 52.50^{\prime \prime}$ \\
\hline 30 & $-03^{\circ} 05^{\prime} 56.20^{\prime \prime}$ & $-59^{\circ} 58^{\prime} 12.68^{\prime \prime}$ & $-03^{\circ} 00^{\prime} 20.68^{\prime \prime}$ & $-60^{\circ} 12^{\prime} 19.64^{\prime \prime}$ & $-02^{\circ} 53^{\prime} 27.70^{\prime \prime}$ & $-60^{\circ} 05^{\prime} 52.90^{\prime \prime}$ \\
\hline
\end{tabular}

A binary matrix was constructed from the obtained fragments, in which zero and one indicated absence and presence of fragments, respectively. The data were used in the construction of a matrix of genetic distances between individuals, based on the arithmetic complement of the Jaccard coefficient, and between populations from the genetic distance of Nei (1978).

A dendrogram was constructed by UPGMA analysis (Unweighted Pair Group Method using Arithmetical Averages) with the aid of the R statistical program (R Development Core Team, 2017) to visualize the genetic differentiation among the $A$. acaule individuals. The adequacy of the cluster analysis to the original data was evaluated by the co-optic correlation coefficient. Non-metric multidimensional scaling analysis (NMDS) was subsequently applied, in which greater dispersion of the units was identified as having greater genetic dissimilarity. The vegan package of the $\mathrm{R}$ program was used (Oksanen et al., 2013) to obtain this analysis.

The Bayesian approach implemented in Structure v.2.4 software (Pritchard et al., 2000) was used to reveal the structures of the populations. The mixed model was considered for the analyses with frequencies correlated with a priori incorporation of the information about the sampling sites. Grouping values (K) ranged from 1 to 8, with five replicates for each tested $\mathrm{K}$ value. The most probable $\mathrm{K}$ value was determined by the $\Delta \mathrm{K}$ criterion described by Evanno et al. (2005).

Assuming populations are in Hardy-Weinberg equilibrium, the Popgene program (Yeh et al., 1999) was used to estimate genetic variation within the three populations. Estimates of genetic diversity included expected heterozygosity $(\mathrm{He})(\mathrm{Nei}$, 1978), Shannon-Weaver (I) genetic diversity index (Shannon \& Weaver, 1949) and percentage of polymorphic loci. In an additional analysis, the gene flow value among populations was estimated.

The Mantel test (Mantel, 1967) was used to investigate the correlation between geographic distance and genetic diversity of populations. The distribution of genetic variation among and within populations was quantified by the molecular variance analysis (AMOVA), performed by the GenALEX v.6.5 program (Peakall \& Smouse, 2012). The significance test for AMOVA estimation was based on bootstrap, considering 10,000 re-samples.

\section{RESULTS AND DISCUSSION}

The oligonucleotide combinations analyzed in the three A. acaule populations showed high levels of polymorphism (Table 2). A total of 200 loci were detected from three pairs of primers, of which 198 (99\%) were polymorphic. There was a variation of 59 to 72 polymorphic loci by oligonucleotide combination. Although the other combinations showed similar results, the $\mathrm{E}+\mathrm{AAC} / \mathrm{M}+\mathrm{CAC}$ combination obtained better amplification. The percentage of polymorphic loci was higher than that obtained by Cardoso et al. (2000) working with Euterpe edulis. Using five combinations of AFLP primers, these authors obtained 429 loci, of which 395 (92\%) were polymorphic.

Table 2. Polymorphism in Astrocaryum acaule subsamples detected by three oligonucleotide combinations using AFLP markers.

\begin{tabular}{ccccc} 
Oligonucleotide combinations & Total loci & Polymorphic loci & Polymorphism (\%) & Size range $(\mathbf{P b})$ \\
\hline E+ACA/M+CGC & 60 & 59 & 98.33 & $50-500$ \\
E+AAC/M+CAC & 72 & 72 & 100.00 & 98.53 \\
E+AAC/M+CGA & 68 & 67 & 99.00 & - \\
Total & 200 & 198 &
\end{tabular}


Based on the 198 AFLP polymorphic fragments, the genetic similarity relationships among $A$. acaule individuals were characterized in the form of a dendrogram, enabling separation of the 90 subsamples into several clusters (Figure 2). In this case, the individuals of the Tarumã-Açu population stand out, being able to be gathered in a single group. Together with some individuals from the Tupé population (TU19, TU18 and TU11), the Tarumã-Açu population were genetically divergent from the other analyzed individuals. It is noteworthy that the co-behavior correlation coefficient $(r=0.9011)$ showed good fit of the dendrogram in relation to the dissimilarity matrix.

Although the subsamples of the UFAM and Tupé populations form smaller groups separately, they are generally shown to be genetically close. Although they are located in an urban environment, the individuals collected in the UFAM population belong to a conservation area, and the Tupé population is included in the Tupé Sustainable Development Reserve, with both regions having restricted access to the human population.

Since they keep much of the naturally observed biodiversity intact, these sites are the subject of morphology and reproduction studies of several plant species; however, with less anthropic interference. Unlike the aforementioned populations, the Tarumã-Açu population is located in an area with great human interference, where local residents have free access to the seed collection areas. Thus, this population possibly lost genetic variability due to genetic drift shortly after forest fragmentation, and humans, as an important seed dispersing agent of the species, has been intensifying the gene flow, thus causing greater genetic distance when compared with the other populations from Tarumã-Açu.

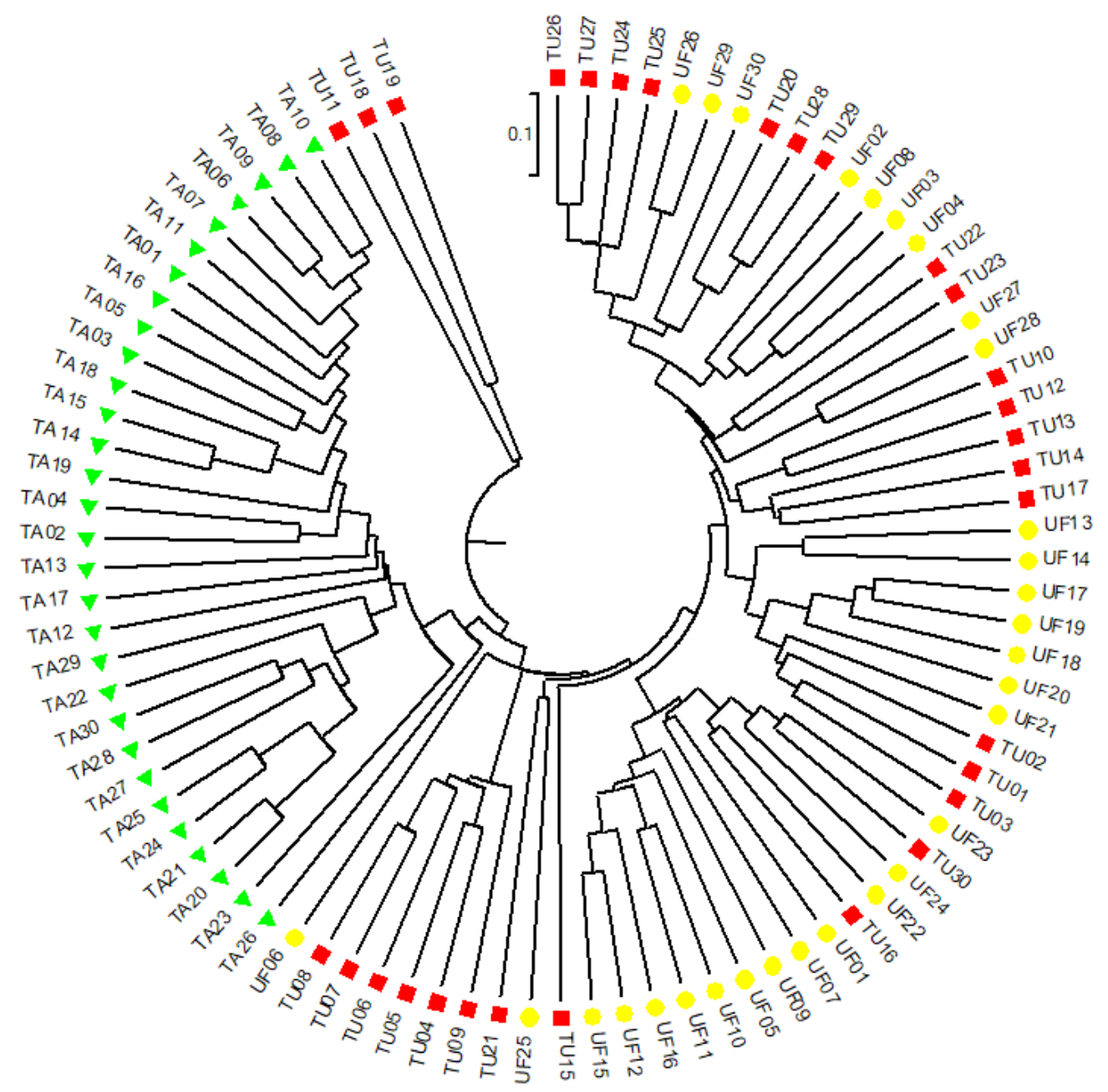

Figure 2. Dendrogram obtained from the arithmetic complement of the Jaccard genetic distance and UPGMA cluster method on 90 Astrocaryum acaule subsamples prospected in UFAM area (yellow circle), Tupé (red square) and Tarumã-Açu (green triangle). Cophenetic correlation coefficient $\mathrm{r}=0.9011$. 
The representation of the similarity relation between the subsamples from two axes was performed by nonmetric multidimensional scaling (NMDS) (Figure 3). The components of the Tarumã-Açu population were closer to each other, forming a group of individuals from the Tupé and UFAM populations, confirming the results of the previous analyses.

Bayesian clustering analysis was performed by the Structure software to determine the genetic patterns of population differentiation and substructuration, and according to the $\Delta \mathrm{K}$ method described by Evanno et al. (2005), the most likely number of clusters was $\mathrm{K}=2$ (Figure 4 ). Graphical visualization of the population structure enabled easy identification of two groups; one formed by the Tarumã-Açu subsamples, and the other formed by most of the subsamples of the UFAM and Tupé populations.

It is possible to understand the relationship between populations through an increasing alignment of the population structure obtained according to the tested $\mathrm{K}$ value (Viana et al., 2013). Thus, UFAM and Tupé individuals were still allocated in the same group, even considering $\mathrm{K}=3$, and the Tarumã-Açu population tended to divide into two groups. This fact emphasizes the high genetic similarity obtained between the first two populations.

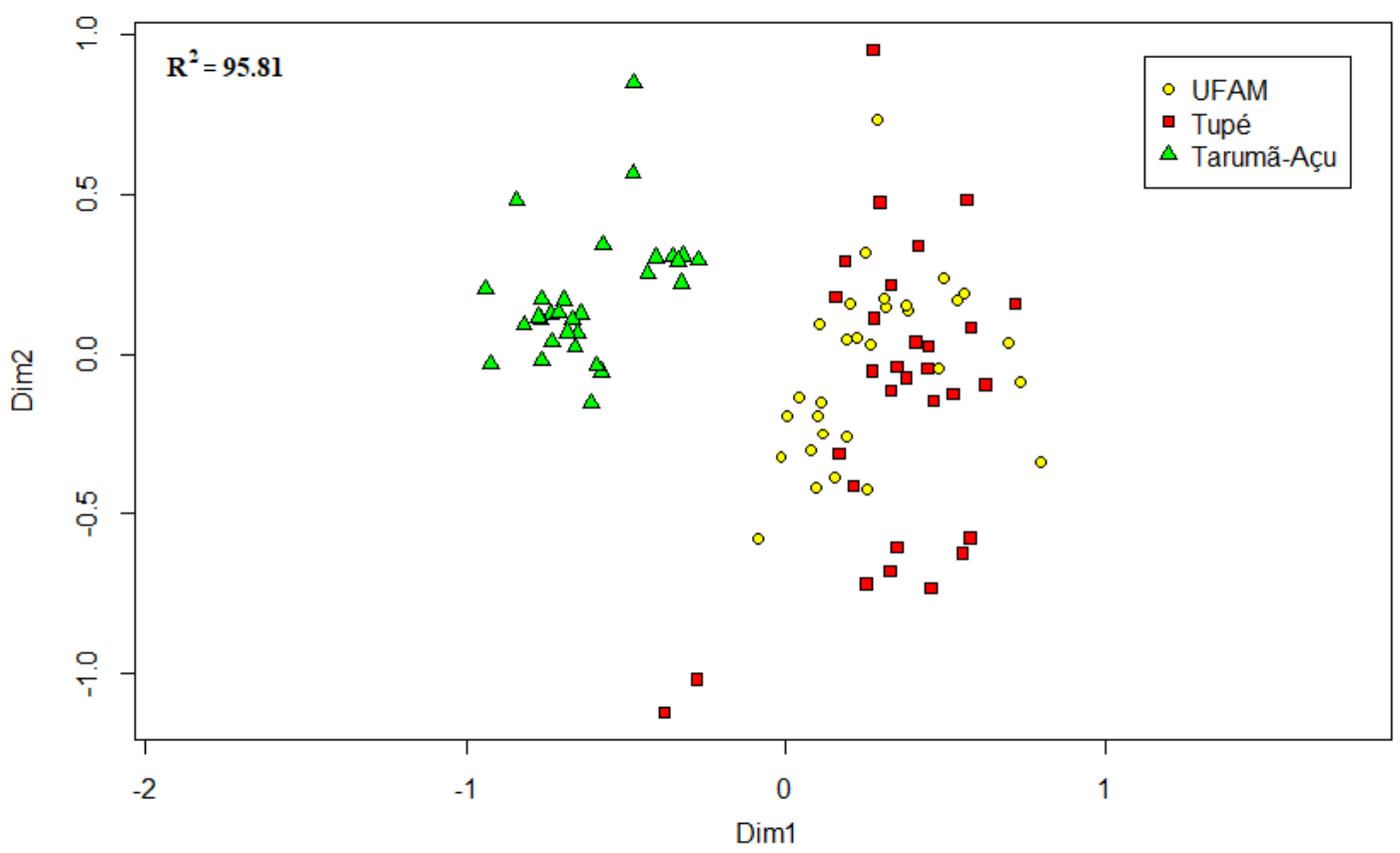

Figure 3. Analysis of non-metric multidimensional scaling of genetic distances between 90 Astrocaryum acaule subsamples prospected from three populations.

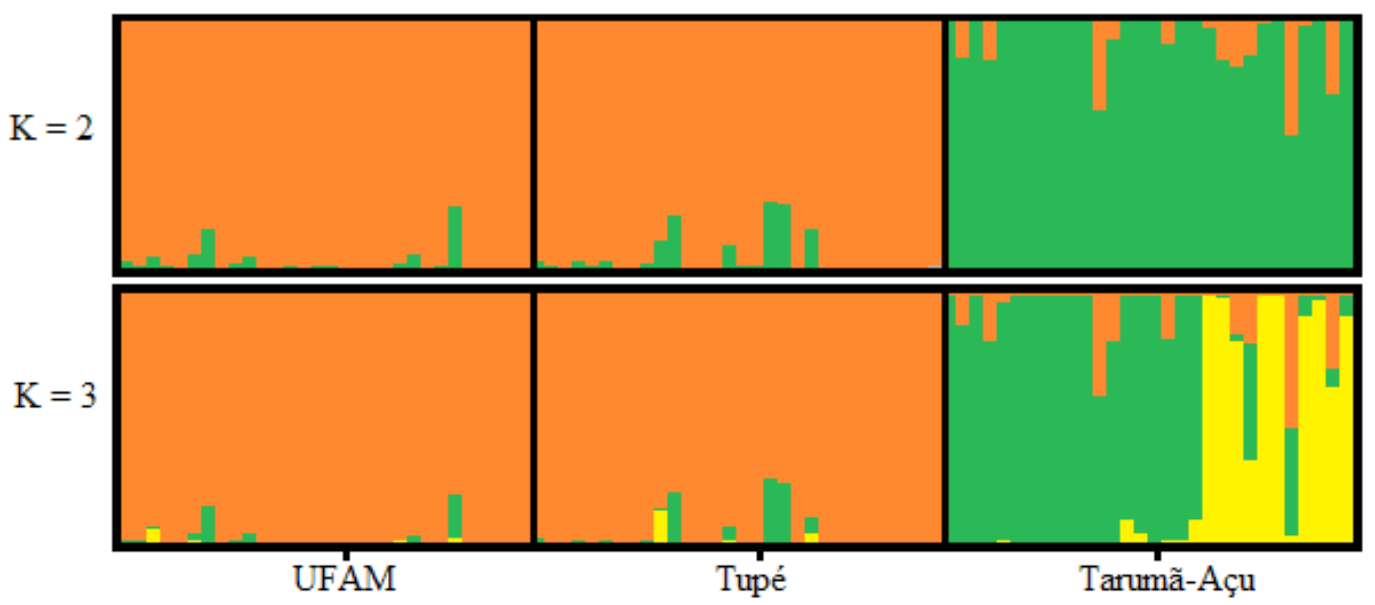

Figure 4. Population structure obtained by Structure software from 90 subsamples prospected from three Astrocaryum acaule populations for different values of clusters $(\mathrm{K})$. 
The genetic distance of Nei (1978) among the pairs of populations was lower between UFAM and Tupé (0.016), and higher between UFAM and Tarumã-Açu (0.098) and Tupé and Tarumã-Açu (0.093). As previously reported, the UFAM and Tupé populations are present in places considered as conservation areas, while the Tarumã-Açu population is in an area of free access which has greater possibility of anthropic interference for the exchange of genes with populations of other regions, and/or a loss of genes caused by deforestation for urban growth and agriculture. These factors may have altered the genetic variability within this population, leading to a greater distance from the UFAM and Tupé populations.

In this study, another important factor that can be correlated with genetic distance must be considered, namely that of physical isolation (Silva \& Souza, 2014). This hinders or inhibits human access to different areas, and can be considered a fundamental factor for the observed distance between isolated populations with restricted access to those populations with free human access for seed exchange.

The hypothesis that the three populations could initially be part of a single population resulting from the same seed bank can be raised. After urban fragmentation and greater physical isolation, UFAM and Tupé populations were genetically distanced from the Tarumã-Açu population.

The Mantel statistic indicated a positive $(\mathrm{r}=0.4076)$ and significant $(p=0.001)$ correlation between the geographic distance and genetic distance of moderate magnitude. Thus, geographical distance influences the genetic divergence of the populations under study; however, this may not be the determining factor. In this case, the physical isolation of the UFAM and Tupé populations also explains that, despite the largest geographic distance between the analyzed populations and the separation by watercourses, they have a higher genetic similarity. In a study of diversity of the Euterpe edulis palm tree, Cardoso et al. (2000) obtained results indicating that genetic distance does not solely depend on geographical distance, although clustering based on genetic distances reflects geographic relationships in most cases. Differing results were observed by Oliveira et al. (2014), indicating that the relationship between populations of Astrocaryum jauari is independent of geographic distortions.

The coefficient of population differentiation (Gst) was equal to 0.1473 . Assuming that the gene flow $(\mathrm{Nm})$ can be estimated based on Gst $(\mathrm{Nm}=0.5(1-\mathrm{Gst}) / \mathrm{Gst})$ and recognizing that all the assumptions required for the calculation are often not met (Whitlock \& McCauley, 1999), the estimated mean gene flow was $\mathrm{Nm}=2.89$ when all populations were considered as a group of populations. This estimate was similar to that obtained by Cardoso et al. (2000) in a study with E. edulis
$(\mathrm{Nm}=2.99)$, and well below that obtained by Adin et al. (2004) for peach palm $(\mathrm{Nm}=4.8)$ from AFLP markers and in river interconnected populations. It is important to emphasize that $\mathrm{Nm}$ values greater than 1.0 indicate that gene flow will be high enough to prevent differentiation between populations due to drift (Slatkin \& Barton, 1989).

The values of expected heterozygosity $(\mathrm{He})$ and Shannon \& Weaver (I) genetic diversity index did not show large variations among the three populations (Table 3 ). However, the highest values of $\mathrm{He}(0.2169)$ and I (0.3413) were found in the Tarumã-Açu population, indicating greater genetic diversity within this population.

These results were already expected, since this population is more likely to receive genetic material from other regions, resulting in greater genetic variability between the individuals of which this population is composed. However, the values obtained for the studied populations were lower than those estimated by Oliveira et al. (2014) when analyzing A. jauari populations based on microsatellite molecular markers, in which the average genetic diversity for a population was 0.56 and for other two 0.63 and 0.58 .

The polymorphism percentage detected within the populations $(84.85 \%, 83.33 \%$ and $85.86 \%)$ indicated that the combinations of primers selected for this study were sufficient to analyze the intraspecific genetic diversity, since a high percentage of polymorphic loci was detected even when the number of individuals analyzed was reduced from 90 to 30 individuals.

The amount of genetic variation obtained by the Molecular Variance Analysis - AMOVA (Table 4) showed that $74.58 \%$ of the genetic variability is found among individuals within the populations and $25.42 \%$ among the analyzed populations. These results show that similar sampling and/ or conservation strategies may not be equally effective in all analyzed populations.

Table 3. Genetic diversity within Astrocaryum acaule populations and in the species.

\begin{tabular}{lcccc} 
Population & $\mathbf{N}$ & $\mathbf{P}(\%)$ & He & $\mathbf{I}$ \\
\hline UFAM & 30 & $84.85 \%$ & $\begin{array}{c}0.2012 \\
( \pm 0.0117)\end{array}$ & $\begin{array}{c}0.3222 \\
( \pm 0.0162)\end{array}$ \\
\hline Tupé & 30 & $83.33 \%$ & $\begin{array}{c}0.1864 \\
( \pm 0.0112)\end{array}$ & $\begin{array}{c}0.3034 \\
( \pm 0.0156)\end{array}$ \\
\hline Tarumã-Açu & 30 & $85.86 \%$ & $\begin{array}{c}0.2169 \\
( \pm 0.0123)\end{array}$ & $\begin{array}{c}0.3413 \\
( \pm 0.0169)\end{array}$ \\
\hline Species & 90 & $100.00 \%$ & $\begin{array}{c}0.2363 \\
( \pm 0.1385)\end{array}$ & $\begin{array}{c}0.3819 \\
( \pm 0.1819)\end{array}$
\end{tabular}

$\mathrm{N}$ : sample size; P: polymorphism percentage; He: expected heterozygosity of Nei (1978) (assuming the Hardy-Weinberg equilibrium); I: Shannon \& Weaver (1949) genetic diversity index. The standard deviations of the considered parameters are within parentheses. 
Table 4. Distribution of genetic variation among and within natural Astrocaryum acaule populations.

\begin{tabular}{lcccc}
$\begin{array}{l}\text { Source of } \\
\text { Variation }\end{array}$ & GL & $\begin{array}{c}\text { Mean } \\
\text { Square }\end{array}$ & $\begin{array}{c}\text { Component } \\
\text { of Variance }\end{array}$ & $\begin{array}{c}\% \text { of } \\
\text { Variation }\end{array}$ \\
\hline $\begin{array}{l}\text { Among } \\
\text { Populations }\end{array}$ & 2 & 296.3778 & $8.9991^{\star *}$ & 25.42 \\
$\begin{array}{l}\text { Within de } \\
\text { Populations }\end{array}$ & 87 & 26.4034 & $26.4034^{\star *}$ & 74.58 \\
\hline Total & 89 & 32.4703 & 35.4025 & 100.00 \\
\hline Fst $=0.2542$ & & & & \\
$* * \mathrm{P}<0.01$ & & & &
\end{tabular}

The results found agree with those reported in the literature for natural populations of tropical tree species, which generally show that most of the genetic diversity is found within populations (Almeida et al., 2015; Rossi et al., 2014). Studies with other palm species have found similar results, as in a study by Gomes et al. (2011), in which the authors reported that the variability between and within M. flexuosa populations was 22.82 and $77.18 \%$, respectively. Buttow et al. (2010) obtained $83.68 \%$ within B. capitata populations and $13.67 \%$ among them, and Cardoso et al. (2000) obtained $57.40 \%$ within and $42.60 \%$ among $E$. edulis populations.

The results found in this study suggest that a large part of the genetic variation of the species is intrapopulational. Thus, usage and conservation plans of the species must observe the genetic variability found in these populations to guarantee the preservation of their genetic resources.

The genetic variability pattern found in A. acaule should be considered for conservation, and a representative sample of the group of genes contained in the individuals of each group should be sampled with the sampling of individuals from both groups ( 1 - Tarumã-Açu and 2 - UFAM and Tupé), since the greatest diversity is within the populations. To perform genetic conservation, this sampling may lead to a high number of individuals, composing an ex situ collection, since the collections established in the field require permanent resources for maintenance. In this way, the best strategy would be to promote participatory in situ conservation in the natural occurring areas of $A$. acaule.

\section{CONCLUSIONS}

Physical isolation of $A$. acaule populations enables greater maintenance of their genetic identity, as anthropic action is an important agent that has been modifying the genetic diversity in natural populations of the species.

The distribution of genetic diversity in the studied $A$. acaule populations was greater within the populations than among them, being necessary to obtain representative samples of each of the genetically distinct groups for the genetic conservation of the species. Therefore, in situ conservation is more recommended.

\section{SUBMISSION STATUS}

Received: 7 Feb. 2018

Accepted: 13 Dec. 2018

Associate editor: Evânia Galvão Mendonça

\section{CORRESPONDENCE TO}

\section{Mágno Valente}

Av. Onça Pintada, s/n, CEP 69735-000, Presidente Figueiredo, AM, Brasil

e-mail: magnosavio@yahoo.com.br

\section{FINANCIAL SUPPORT}

Coordenação de Aperfeiçoamento de Pessoal de Nível Superior (CAPES) and Fundação de Amparo à Pesquisa do Estado do Amazonas (FAPEAM).

\section{REFERENCES}

Adin A, Weber JC, Sotelo Montes C, Vidaurre H, Vosman B, Smulders MJ. Genetic differentiation and trade among populations of peach palm (Bactris gasipaes Kunth) in the Peruvian Amazon: implications for genetic resource management. Theoretical and Applied Genetics 2004; 108(8): 1564-1573. 10.1007/s00122-003-1581-9

Almeida FVD, Lopes MTG, Valente MSF, Bentes JLS. Diversidade genética entre e dentro de populações de Cenostigma Tocantinum Ducke. Scientia Forestalis 2015; 43(108): 753-762. 10.18671/scifor.v43n108.1

Buttow MV, Castro CM, Schwartz E, Tonietto A, Barbieri RL. Caracterização molecular de populações de Butia capitata (Arecaceae) do Sul do Brasil através de marcadores AFLP. Revista Brasileira de Fruticultura 2010; 32(1): 230-239. 10.1590/S010029452010005000001

Cardoso SRS, Eloy NB, Provan J, Cardoso MA, Ferreira PCG. Genetic differentiation of Euterpe edulis Mart. populations estimated by AFLP analysis. Molecular Ecology 2000; 9(11): 1753-1760. 10.1046/j.1365294x.2000.01056.x

Creste S, Tulmann Neto A, Figueira A. Detection of single sequence repeat polymorphisms in denaturing polyacrylamide sequencing gels by silver staining. Plant Molecular Biology Reporter 2001; 19: 299-306. 10.1007/BF02772828

Cruz CD, Ferreira FM, Pessoni LA. Biometria aplicada ao estudo da diversidade genética. Visconde do Rio Branco: Suprema; 2011.

Evanno G, Regnaut S, Goudet J. Detecting the number of clusters of individuals using the software STRUCTURE: a simulation study. Molecular Ecology 2005; 14(8): 2611-2620. 10.1111/j.1365294X.2005.02553.x

Gomes LRP, Lopes MTG, Bentes JLS, Barros WS, Costa Neto PQ, Contim LAS. Genetic diversity in natural populations of Buriti (Mauritia flexuosa L. f.). Crop Breeding and Applied Biotechnology 2011; 11(3): 216-223. 10.1590/S1984-70332011000300003 
Lopes R, Lopes MTG, Figueira AVDO, Camargo LEA, Fungaro MHP, Carneiro MS, Vieira MLC. Marcadores moleculares dominantes (RAPD e AFLP): aspectos técnicos e interpretação genética. Biotecnologia, Ciência e Desenvolvimento 2003; 29: 64-68.

Mantel N. The detection of disease clustering and a generalized regression approach. Cancer Research 1967; 27(2): 209-220.

Murray MG, Thompson WF. Rapid isolation of high molecular weight plant DNA. Nucleic Acids Research 1980; 8(19): 4321-4325. 10.1093/nar/8.19.4321

Nei M. Estimation of average heterozygosity and genetic distance from a small number of individuals. Genetics 1978; 89(3): 583-590.

Oliveira LDS, Ramos SLF, Lopes MTG, Dequigiovanni G, Veasey EA, Macêdo JLV et al. Genetic diversity and structure of Astrocaryum jauari (Mart.) palm in two Amazon river basins. Crop Breeding and Applied Biotechnology 2014; 14(3): 166-173. 10.1590/1984-70332014v14n3a25

Oksanen J, Blanchet FG, Friendly M, Kindt R, Legendre P, McGlinn $\mathrm{D}$ et al. Vegan: community ecology package. [S. 1.]: R package 2.0$10 ; 2013$.

Pacheco KMM, Ortuño BH, Miranda IPA, Nascimento CC, Pacheco AS. Oportunidades e limitações do uso da fibra natural de tucumã-i (Astrocaryum acaule) para a gestão e desenvolvimento de produtos semi-industriais. In: $8^{\circ}$ Congresso Brasileiro de Gestão de Desenvolvimento de Produto; 2011; Porto Alegre. Porto Alegre: UFRGS/FEEng; 2011.

Peakall R, Smouse PE. GenAlEx 6.5: genetic analysis in Excel. Population genetic software for teaching and research: an update. Bioinformatics 2012; 28(19): 2537-2539. 10.1093/bioinformatics/bts460

Pritchard JK, Stephens M, Donnelly P. Inference of population structure using multilocus genotype data. Genetics 2000; 155(2): 945-959.

R Development Core Team. R: a language and environment for statistical computing [Internet]. Vienna: R Foundation for Statistical Computing; 2017 [cited 13 Mar. 2020]. Available from: http:// www.r-project.org
Ramos SLF, Macêdo JLV, Lopes MTG, Batista JS, Formiga KM, Silva PP et al. Microsatellite loci for tucumã of Amazonas (Astrocaryum aculeatum) and amplification in other Arecaceae. American Journal of Botany 2012; 99(12): e508-e510. 10.3732/ajb.1100607

Rossi FS, Rossi AAB, Dardengo JFE, Brauwers LR, Silva ML, Sebbenn AM. Diversidade genética em populações naturais de Mauritia flexuosa L. f. (Arecaceae) com uso de marcadores ISSR. Scientia Forestalis 2014; 42(104): 631-639.

Shannon CE, Weaver WA. The mathematical theory of communication. Urbana: University of Illinois Press; 1949.

Silva MSF, Souza RM. Padrões espaciais de fragmentação florestal na Flona do Ibura - Sergipe. Mercator 2014; 13(3): 121-137. 10.4215/ RM2014.1303. 0009

Slatkin M, Barton NH. A comparison of three indirect methods for estimating average levels of gene flow. Evolution 1989; 43(7): 1349-1368. 10.1111/j.1558-5646.1989.tb02587.x

Viana JMS, Valente MSF, Silva FF, Mundim GB, Paes GP. Efficacy of population structure analysis with breeding populations and inbred lines. Genetica 2013; 141(7-9): 389-399. 10.1007/s10709-013-9738-1

Viegas MP, Silva CLSP, Moreira JP, Cardin LT, Azevedo VCR, Ciampi AY et al. Diversidade genética e tamanho efetivo de duas populações de Myracrodruon urundeuva Fr. All., sob conservação ex situ. Revista Árvore 2011; 35(4): 769-779. 10.1590/S0100-67622011000500002

Vos P, Hogers R, Bleeker M, Reijans M, Van de Lee T, Hornes M et al. AFLP: a new technique for DNA fingerprinting. Nucleic Acids Research 1995; 23(21): 4407-4414. 10.1093/nar/23.21.4407

Wallace AR. Palmeiras da Amazônia e seus usos. Manaus: Edua; 2014.

Whitlock MC, McCauley DE. Indirect measures of gene flow and migration: FST $\neq 1 /(4 \mathrm{Nm}+1)$. Heredity 1999; 82: 117-125. 10.1038/ sj.hdy. 6884960

Yeh FC, Yang R, Boyle TR. Popgene version 1.32 Microsoft Windowsbased freeware for population genetic analysis. Edmonton: University of Alberta; 1999. 